\title{
An Intersection of Racism and Sexism in Toni Morrison's Sula
}

\author{
Samrakshika Thapa \\ Asst. Lecturer \\ Makawanpur Multiple Campus \\ Email: metaphorsamra2020@gmail.com
}

Received: November 09, 2020; Revised \& Accepted: December 11, 2020; Published: February 18, 2021 (C) Copyright: Thapa (2021).

\begin{abstract}
This study analyzes female friendship in Sula and also focuses on the impact of race, class and gender on women's relationships. The novel emphasizes how women face the challenges of patriarchal institutions and other attempts to subjugate through polygamy, constraints of tradition, caste prejudice and political instability. Thus, the chief aim of this study is to show how the black women are treated unfairly and suffer from male domination within their community also. The study portrays the healing powers of female bonding, which allows women to overcome prejudice and survival, to enjoy female empowerment, selfhood establishment and to extend female friendship into female solidarity that participates in nation building. However, another conclusion focuses on the patriarchy which constitutes a threat to female bonding and usually causes women's estrangement.
\end{abstract}

Keywords: discrimination, domination, identity, intersection, patriarchy, racial, sexual.

\section{INTRODUCTION}

Sula is a feminist novel advocating for equality among humanity without discrimination in terms of sex and race. This addresses the confusing mystery of human emotions and relationship and ultimately concluding the social conventions. Throughout the novel, the narrator depicts these two female characters to apply the diametrically opposed terms of good/evil, right/wrong, black/white, self/other etc as set of opposition to the characters and their actions. It claims that the two marginalized African-American female personages in the novella, Nel and Sula are noteworthy and influential characters as they are shown a critical position which undermines the predominantly masculine enterprise. Trudier Harris appeal to African-American folk traditions as basis for Sula. Morrison's novel scrutinizes the issue of relations between black and white in America. Sula is marginalized in two folds, she goes to college, sleeps with white man, does not marry and rejects to be mother. Morrison has created a black community of bottom linked strongly with its past values and beliefs so any attempt to posit a new ethic will set the entire community in a whirlwind of disbelief and fear. The text, Sula examines the constructions of Black womanhood and manhood, particularly through the character of Sula, who rejects the conventional black female role. Sula determined to introduce herself outside of 
the traditional role of domesticity and must find an identity deeper than the standard identities of wife and mother. She seeks to find an internally defined identity rather than one informed by the paradigm of family. Yet, by refusing these expected, so-called natural roles, she is rejected by the community and strengthens their own enactment of traditional gender roles in the face of her unconventional attitudes. Sula leaves the village and returns with different experiences; now she can no longer live by the old rules. Sula's activities, after her return, engenders all kinds of responses and accusation. She sleeps not only with her best friend's husband and her neighbors' husbands but also with white men.

In this context, this research tries to find out what Morrison has in her mind while creating black female characters like Sula who is bold enough to reject to be a mother and goes against the role prescribed by her patriarchal black society. Black women's common experience of oppression urges them to form bonds in order to fight back the impact of race, class and gender. Female friendship not only helps women counteract the effects of patriarchy but it also provides them with comfort, security and even healing. Although all novels acknowledge the importance of female friendship, Morrison deliberately chooses to portray failed relationships in order to patriarchy and warn women about the danger a lack of bonding is likely to cause in their lives. From this Morrison's novel explores mythic themes of family and responsibility while offering a fundamental ethos of hope and love and also the importance contribution in presenting women as a source of unity.

In racism and sexism, there is nothing obvious of natural about our ideas of sex and race. As Colette Guillaumin reminds us, this naturalist ideology hides the relations which constitute 'racial' and 'sexual' categories; groups which are interconnected in such a way that each one is a function of the other are deemed to be distinct and discrete entities characterized by closure. The processes through which these categories are constructed, more importantly, the appropriation of their labour is occluded. As a result, 'race' and 'sex' are treated as biologically and or socially constituted independent variables, causing the observed social positions and inequalities. All men, irrespective of class or race, benefit, through in different ways, from a system of domination where women are economically, politically, legally and culturally subordinated to men. Firestone, faithful to De Beauvoir, argues that women's position in society can be understood in terms of their position in the domestic mode of production, which exists alongside the capitalist mode of production. There is an attempt to separate the biological fact from social and psychological characteristics; biological 'race' does not determine behavior and social position as there exists no necessary relation between these two components. First, Sex is seen as evidence, there are two biological sexes and therefore, two sexual categories. 'Sex' is an independent variable, it determines the place occupied in the sexual division of labour and in society in general. Second, biological sex is separated from gender: 'you are not born a woman, you become one'.

In this text the narrator comments that union between black woman and white man "was literally unthinkable" in Bottom (146). In her society all unions between white men and black women are regarded as rape. Sula, unanticipated black female character in Black literature, represents new black female identify denying all kinds or repression. In building up the image of 
Nel and Sula as doubles, Morrison gives indications throughout the novel of how the two women are actually two halves of person. For example, when Sula returns to Bottom, Nel thinks that her friend's return was "like getting an eye back" and that talking to Sula "had always been a conversation with herself" (17). The cause of the Nel and Sula's sudden estrangement offers Morrison an opportunity to examine the way both characters react to the values and expectations of the African-American community.

The lives of women are very poor. They are rooted to past and values handed over from centuries. It focuses for equality among humanity without discrimination in terms of race and sex. When Sula tries to establish her identity she is despised and abused by the people.

\section{LITERATURE REVIEW}

Fredirick R. karl illuminates: Sula, the character, disrupts every expectations the black community has for a woman, consciously damning herself in the eyes of others to prove to herself what a black woman can do (579). She is unpredictable. She is defined as "bitch" (145). It is supposed that she sleeps with white men, she discards black men, even she sleeps with the husband of her best friend Nel. The lives and the social status of black were very poor. They are more rooted to past and values handed over from centuries. That's why they needed different strategies to represent in the community. And here Morrison envisioned a bold female character named Sula who seeks for sexual liberation, freedom of movement and indifference to social commitments. "Each had discovered years before that they were neither white nor male" (which again emphasizes the double oppression of the black women, based on race and gender) "and that all freedom and triumph was forbidden to them, they had set about creating something else to be" (19). However, in the end, only Sula appears to take charge of her own existence without the permission or approval of her family or community. Nel's approach to becoming whole is to take refuse in an unequal marriage. For Nel's mother, marriage is one of conditions of living that defines a women's place and Nel accepts a similar arrangement for herself. In marrying Jude, Nel gives up her youthful dreams of "trips she would take" (21) and being independent. Nel becomes "obedient and polite", as her mother gradually "drives her daughter's imagination underground" (24). Therefore, it is obvious why, years later, Nel has difficulties in reconciling her individualism with the roles the black community expects her to play.

According to Mel Watkins in Sexism, Racism and Black Women Writers argues that in the great majority of their novels, black women indicate that "sexism is more oppressive than racism" (36). He continues that blacks are always portrayed in a negative manner without exception. As Sula and Jude treated and dominated which is an example of it. Again, Karl remarks "Toni Morrison, in Sula as well as in The Bluest Eye, Song of Solomon and Tar Baby works through many of those lower class concerns but with the added dimension of the black women struggling to assert herself (579)". She resists any authority or control, an aspect obvious even from Sula's childhood days when would go up to her attic to run away from and mark her resistance to tradition. She rejects the advice to settle down and have babies, replying "I don't want to make somebody else, I want to make myself' (25). Sula's manner and tone of voice make her much more forceful female than what the society during 1930s, the time during the novel is place. It could be argued that her economic position within the working class served to 
free her from the stereotypical gender constraints and allowed her to be the type of person she really wanted to be - a dominant, independent, single woman. Later on she is surprised and saddened by Nel's choosing Jude over her, since she had not expected Nel to behave "the way the others would have" (26). Nel criticizes Sula for her independent behavior, saying, "You can't do it all. You a woman and a colored woman at all. You can't act like a man," (142). And Sula simply tells: You say I'm a woman and colored. Ain't that the same as being a man ?" (142). In her conception, the two terms, "woman" and "colored," serve to cancel each other out, to make her, in effect, a man. Sula's passionate rejection of feminine roles is perhaps which is defeminization of the Black woman: yet in her own culture, Sula is viewed with suspicion and even outcast for "acting like a man" (142)

William Edward Burghardt Du Bois in The Crisis he says, "We want everything said about said about us to tell of the best and highest and noblest in us... we fear that the evil in us will be called racial, while in others, it is viewed as individual" (55-56). Sula, a girl, who rebels against the rule that exist in the black community which is off course against racism and sexism. Whatever they do is evil for other. They never treated in individual. Toni Morrison places blackwhite relations on a secondary level to allow for a greater focus on the struggles within the African-American community: Sula and Shadrack are pushed aside by the blacks just because they do not adhere to their norms and expectations. The use of racism and sexism as a means of highlighting the double oppression felt by African-American women are: To what extent does the African- American family and community influence decisions and about important events in life. The novel links these issues to adolescence and portrays how two young girls, despite belonging to the same community, come to, on account of their very different backgrounds, live very different lives when becoming adults. The familial backgrounds of the two girls, Nel and Sula are founded on very different moral codes, one following the conventional gender roles of the community, and the other not. Sula has many affairs, some with white men. However, she finds people following the same boring routines elsewhere, so she returns to Bottom. Upon her return, the town Bottom regards her as the personification of evil for her blatant disregard of social conventions and their hatred in past of her rest life. And because of social conventions and international disregard for rules and norms, her best friend Nel also breaks her friendship.

In order to better understand the oppression of black women in the United States, one must look at the way the social structures and social environment are influenced by race, class or gender. Of course, there are many other intersecting dimensions that can be taken into consideration, depending on the social group that is investigated: for example, sexuality, religion, nationality, disability etc. Toni Morrison has juxtaposed the world of Nel next to the world of Sula who seeks her own life exploring her emotions and imagination. Her life is her own, she does not care for other's business unless it pleases her. She is not interested in nailing with anybody else, so much. Sula pursues herself she is estranged from others. Kalerie Smith rightly mentions: "Sula centers on a character who believes that she can create for herself an identity that exists beyond community and social expectations" (276). Sula tells the story of two women who renegotiate the pressures of place and person through their long friendship, which is not without moments of rupture and discord. The growing bond between Nel Wright and Sula Mae 
Peace as well as their complementary personalities are first revealed to us by the contrasting features of the land.

The mother-Daughter Relationship is firmly contextualized mostly in the society. Diane Gillespie and Missy Dehn Kubitschek points that "women-centered psychological interpretations of female experience emphasis the web-like nature of women's social relationships" (29). In most of Nel and Sula personifies debased aspects of conventional female morality; her mother largely shapes this phase of development. Hannah, Sula's mother, sleeps with as many men as she can. Is she a prostitute? The research has tries to depict the Black Feminism in Morrison's Sula by portraying the strong and weak portion of the male and female characters' traits. The protagonist, Sula is entirely succeeded to set up her full autonomy by protesting against the patriarchal pre-existed social values and norms of Afro-American society. As Sula walks through streets and people stare at her. Finally she gets Eva's house. Eva says that "I might have knowed them birds meant something" (91). Their relationship is cold. Eva tells Sula to marry and settle down but Sula denies and says "I don't want to make somebody else. I want to make myself" (92). She exposes the quest of self identity. Sula embodies the Black radical feminist, which seems to be selfish for the society of the Bottom: "selfish. Ain't no woman got no business floating around without no man"(92). She never wants anybody. She wants to be free from rules and traditional norms. In the town people are shucked by Sula's behavior. Then people take her as evil and trouble for bringing accident, drought and deaths. The people of Bottom outcasts her and makes her as a Pariah.

And critic like Addison Galye on Blueprint for Black Criticism continues, "these men and women are positive" characters, functional "alternatives to the stereotypes of blacks," and thus warriors in the "struggle against American racism" (44). Here critic's view is the portrayal of black characters which is uniformly as "Negative". But either men or women they are positive. We can find the lives of black people victimized and exploited by non-other than white.

Self definition is a dangerous activity, for any woman to engage in, and especially for Black woman. Thus, Sula's attempt for self definition earns her pariah status in Medallion. Morrison pictures her as an embodiment of a radically new Black feminist and her character has been an effect of freeing the fettered minds from the oppressive tentacles of a past which prevents them from progressing and projecting a new vision. Since the first leading of Black people in America, they have been exploited by the white people. Mostly the black women are victims of both racial and sexual oppression. For Sula "nothing was ever different, they were all the same... that's the same sun I looked at when t was twelve, the same pearl trees" (147). She doesn't find any newness in life and thinks that if she lives a hundred years, her hair will grow from the same holes; the urine will flow the same way. She is fed up at the sameness of life. "There are not any more new signs and I have sung all the ones there are" (137). Eva acts like a phallic mother who assumes godlike powers of control over naming, creation and destruction. Eve loses her leg in patriarchy, so she is defined as woman who lacks something i.e penis. For the sake of her survival, she cuts off her leg. And same self mutilation of Eva is repeated in the scene in which Sula cuts off the tip of finger to threaten the boys while returning from school. 
Sula courageously says "if I can do that to myself, what do you suppose I'll do to you?" (54-55). She exposes such action to prove her violent nature.

Morrison's protagonist character, Sula, showing her courageous and challenging activities in the novel. She has successfully established her New World Woman in the AfroAmerican community. She has presented feminine struggle and challenges the restrictions imposed by Black community over Black women.

\section{METHODOLOGY}

This text is an analytical based research. It has used a close, discursive analytical style which has drawn on the intersection of racism and sexism. As research and research concern is with the methodology of race and sex, it mainly falls back on Colette Guillaumin who suggest these issues are not separate but close to each other.

\section{CONCLUSION}

Toni Morrison's Sula is a novel in the tradition of African-American literature, exploring racism and sexism. The two characters show their intimate childhood friendship to their diverging paths as adults and also drawn together out of a shared lived experience as black women in a white patriarchal society. Morrison, presents patriarchal institutions in her novels as threats to women's relationships. Sula maps a discourse of maternal intimacy as a means of reclaiming a sense of self as well as a sense of community. Thus studying and analyzing Morrison's books from a Black feminist outlook brings perception into diverse life experience of the black female's life in a racist and patriarchal society. Here, it also clarifies that the most significant factors that influences the building of African -American's identity. Here women try to revolt against the patriarchal society by living, accepting enduring and finally challenging the so-called norms, the same family and society for their position, but especially in case of black people, they are an internalized projection of white people's fears. In this reading one might easily conclude that social and racial stereotypes undermine and intersect with black women's journey towards their selfhood. Because of double burden (racism and sexism) it makes hard to form their identities. Actually Freedom for them (black women) is impossible if they do not strongly revolt.

\section{WORKS CITED}
Diane Gillespie , and Kubitschek Missy Dehn. Who Cares? Women-centered Psychology in Sula. Toni Morrison's Fiction: contemporary criticism, Ed David L. Middleton (pp. 61-94). New York: Garland, 1997.

Du Bois, William Edward Burghardt. "Negro Art." The Crisis 22.2 (1921): 55-56.

Fredirick, Karl. Black Writers - Jewish Writers - Women Writers. American Literature. Ed. Boris Ford. London: Penguin books Ltd, 1991.

Gayle, Addison. "Blueprint for Black Criticism." First World 1.1 (1977): 44.

Guillaumin, Colette. Racism, Sexism, Power and Ideology. USA and Canada: Taylor and Francis, 2004. 
International Research Journal of MMC (IRJMMC)

Vol. 2

Morrison, Toni. " Unspeakable Things Unspoken: the Afro-American Presence in American Literature." Michingan Quartely Review (1988): 1-34.

—. Sula. Hudson street, New York: Penguin Books Ltd. Hudson street, New York:: Penguin Books Ltd, 1993.

Smith, Valerie. Song of Solomon: Continuities of community. Toni Morrison: Critical Perspectives Past and Present. Ed. Jr. and K.A Appiah Henry Louis Gates. New York: Amistad Press Inc, 1993.

Watkins, Mel. "Sexism, Racism and Black Women Writers." New York Times Book Review 36 (1986). 